Western University

Scholarship@Western

Civil and Environmental Engineering

Civil and Environmental Engineering

Publications

Department

2015

Seismic Capacity of Reinforced Concrete Interior Flat Plate

Connections

Maged A. Youssef

Western University, youssef@uwo.ca

A O. Chowdhury

Mohamed E. Meshaly

Alexandria University

Follow this and additional works at: https://ir.lib.uwo.ca/civilpub

Part of the Structural Engineering Commons

Citation of this paper:

Youssef, Maged A.; Chowdhury, A 0.; and Meshaly, Mohamed E., "Seismic Capacity of Reinforced Concrete Interior Flat Plate Connections" (2015). Civil and Environmental Engineering Publications. 190.

https://ir.lib.uwo.ca/civilpub/190 


\title{
Seismic Capacity of Reinforced Concrete Interior Flat Plate Connections
}

\author{
Maged A. Youssef ${ }^{*}, 1$, Abu Obayed Chowdhury ${ }^{1}$, Mohamed E. Meshaly ${ }^{2}$ \\ ${ }^{1}$ Western University, Department of Civil and Environmental Engineering, London, Ontario N6A 5B9, Canada. \\ ${ }^{2}$ Alexandria University, Department of Structural Engineering, Alexandria, Egypt.
}

\section{Abstract}

Flat plates are widely used in reinforced concrete buildings. Their design is usually based on the shear forces and bending moments produced by the gravity loads. During seismic activities, the lateral building deformations induce additional shear forces and bending moments that they must withstand. To evaluate the seismic moment capacity of a flat plate system, an effective slab width needs to be defined. In this paper, grillage analysis is utilized to predict the nonlinear lateral behaviour of flat plate buildings. A comprehensive parametric study is used to evaluate the effective slab width contributing to the lateral strength of residential interior flat plate connections. The studied parameters include span length, bay width, column dimensions, and level of column axial load. Both gravity load designed frames and moment resisting frames are analysed. The effect of the material safety factors is assessed by conducting two sets of analyses using nominal material properties and factored material properties. Equations to estimate the effective slab width are proposed.

Keywords: Modelling, Strength, Flat plate, Effective width, Grillage analysis, Seismic.

* Corresponding author, Associate Professor, Tel.: +1 519 661-2111 Ext. 88661; Fax: +1 519 661-3779, E-mail address: youssef@uwo.ca 


\section{Introduction}

Reinforced Concrete (RC) flat plates simplify the construction process and reduce building heights. For low and moderate seismic zones and a maximum building height of $15 \mathrm{~m}$, they can be considered as part of the lateral load system as allowed by the National Building Code of Canada (NBCC, 2010). For other cases, a stiffer lateral force resisting system such as shear walls must be introduced. The flat plate system deforms laterally either as part of a moment resisting frame or as part of a building. These deformations result in seismic forces and moments that the system must withstand.

Modelling of flat plates using shell elements to predict their seismic behaviour is cumbersome due to both material and geometric nonlinearities. When subjected to service gravity loads, flat plates behave within the elastic range and can be modelled using shell elements or beam elements (grillage analysis). O'Brien and Keogh (1999) discussed the method of modelling a slab by grids of beam elements to predict its elastic behaviour. Two assumptions related to thin plate theory are made: (1) the depth of the slab remains unchanged, and, thus points across the slab thickness deflect vertically by exactly the same amount as points directly above or below them (the assumption is based on the fact that strains in the thickness direction are generally small and have negligible effect on the overall behaviour of the slab) and (2) the deflection of the slab is mainly caused by flexural stresses (effect of shear distortion is ignored).

A common and practical method for seismic analysis of flat plate systems involves analysing two-dimensional frames. The beam elements of these frames represent an effective slab width, which is critical to define the frame stiffness and the flexural capacity of the slab. The Canadian standard for designing concrete structures (A23.3-04, 2004) specifies an effective 
slab width factor $(\alpha)$ of 0.2 . The slab effective width is equal to $\alpha$ times the bay width (B). Based on elastic analysis, Pecknold (1975) presented $\alpha$ values for typical interior panels as a function of the column dimension in the span direction $\left(\mathrm{c}_{1}\right), \mathrm{B}$, and the span length $(\mathrm{L})$. Based on a limited number of experimental tests, Luo and Durrani (1995) proposed an equation to estimate $\alpha$ corresponding to the total unbalanced moment resulting from lateral loads. They also proposed a reduction factor to account for the effect of gravity loads. Their equation is unsuitable for estimating the slab flexural capacity as it corresponds to the total unbalanced moment. Youssef et al. (2014) proposed equations to estimate the effective slab width contributing to the lateral stiffness of a flat plate moment frame. However, these equations are not suitable for estimating the slab flexural capacity. Other available formulas that were based on very limited number of experimental tests include those of Hwang and Moehle (1993) and Grossman (1997).

This paper starts by providing details about the use of grillage analysis to model flat plates. It then presents a comprehensive parametric study for interior residential flat plate connections. Results from this study are used to propose new effective width formulas suitable for calculating the slab flexural capacity considering lateral loads.

\section{Grillage model}

The slab is modelled using a grid of 3D inelastic beam elements. Each beam element represents the concrete and reinforcing bars in a width of the slab equal to the spacing between the elements. Columns are represented using 3D inelastic beam-column elements. The effect of shear deformations on the results is insignificant as compared to flexural deformations (O'Brien and Keogh, 1999), and, thus is neglected. Spacing between the beam 
elements depends on the torsional behaviour of the slab (O'Brien and Keogh, 1999). The torsional constant per unit width of any thin plate is twice the second moment of area per unit width. To maintain this ratio, a grid spacing of about 1.25 times the depth of slab should be used. O'Brien and Keogh (1999) indicated that this spacing might be impractical and can be increased up to three times the slab depth without affecting the solution accuracy. The torsional behaviour of slabs without shear reinforcement is expected to be linear up to failure, and, thus the torsion rigidity was assumed equal to the elastic value.

Fiber modelling approach was employed to represent the distribution of material nonlinearity along the length and cross-section of each member. The sectional stress-strain state of the elements was obtained through the integration of the nonlinear uniaxial stress-strain response of the individual fibers in which the section was subdivided.

Concrete was modelled using the uniaxial nonlinear constant confinement model of Martinez-Rueda and Elnashai (1997). The constant confining pressure provided by the lateral transverse reinforcement was incorporated through the rules proposed by Mander et al. (1988). The parameters that define the model are: concrete compressive strength $\left(f_{c}^{\prime}\right)$, concrete tensile strength $\left(f_{t}\right)$, strain at peak stress $\left(\varepsilon_{0}\right)$, and confinement factor $\left(k_{c}\right)$. A uniaxial bilinear stress-strain model was used to model the reinforcing bars. The parameters defining the model are: the modulus of elasticity $\left(E_{s}\right)$, yield strength $\left(f_{y}\right)$, and strain hardening parameter $(\mu)$. Flexural failure was assumed to occur when the unconfined concrete of the slab reaches its crushing strain that ranges between 0.003 and 0.004 (Park and Paulay, 1972). Shear failure was assumed to occur when the shear force exceeds the nominal shear resistance specified in A23.3-04 (2004). 
The grillage analysis technique was validated by Youssef et al. (2014) using the experimental results by Robertson and Durrani (1990). The technique was found to accurately predict behaviour of the tested slabs up to failure.

\section{Flexural capacity of a flat plate system}

The validated grillage analysis is used to conduct a parametric study to evaluate the effective width that can be used to estimate the nominal and factored flexural capacity of a flat plate system. Two types of connections are considered; connections designed for gravity loads and those designed for lateral loads. Fig. 1 shows a typical connection.

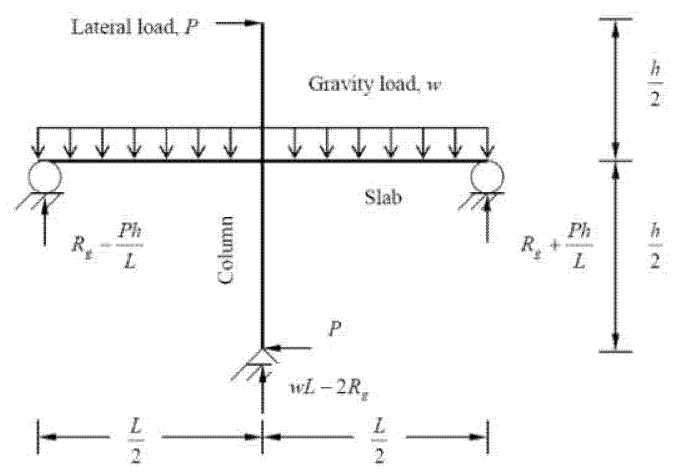

Fig. 1 A typical Interior slab-column connection subjected to gravity and lateral loads.

The considered geometric parameters are: span length, bay width, and column dimension in the span direction. Values for the considered parameters are shown in Table 1. The story height is taken as $3 \mathrm{~m}$. While varying one geometric parameter, the other two parameters are 
assumed to remain constant at the mean value. The variation of the column axial load from floor to floor was considered by designing connections with different column axial loads. Nominal and factored ratios of column axial loads relative to that of the column supporting one storey $\left(\frac{P}{P_{1}}\right.$ and $\left.\frac{P_{f}}{P_{f 1}}\right)$ are shown in Table 1. Compressive strength of concrete and yield strength of steel are taken as 25 and $400 \mathrm{MPa}$, respectively. These values are widely used for flat plate structures.

Table 1: Properties of considered connections

\begin{tabular}{|c|c|c|c|c|c|c|c|c|c|c|}
\hline Connection & $\begin{array}{c}\text { Span } \\
\text { (m) }\end{array}$ & $\begin{array}{c}\text { Bay } \\
\text { width } \\
(\mathrm{m})\end{array}$ & $\begin{array}{c}\text { Square } \\
\text { Column } \\
\text { dimension } \\
(\mathrm{mm})\end{array}$ & $\begin{array}{l}\text { Slab } \\
\text { thickness } \\
(\mathrm{mm})\end{array}$ & \multicolumn{3}{|c|}{$\begin{array}{l}\text { Nominal axial } \\
\text { load ratio, } \frac{P}{P_{1}}\end{array}$} & \multicolumn{3}{|c|}{$\begin{array}{l}\text { Factored axial } \\
\text { load ratio, } \frac{P_{f}}{P_{f 1}}\end{array}$} \\
\hline $\mathrm{C} 1$ & 4 & 6 & 700 & 200 & & & & & & \\
\hline $\mathrm{C} 2$ & 6 & 6 & 700 & 200 & & & & & & \\
\hline $\mathrm{C} 3$ & 8 & 6 & 700 & 270 & & & & & & \\
\hline $\mathrm{C} 4$ & 6 & 4 & 700 & 200 & 1 & 7 & 14 & 1 & 7 & 14 \\
\hline $\mathrm{C} 5$ & 6 & 8 & 700 & 270 & & & & & & \\
\hline C6 & 6 & 6 & 600 & 200 & & & & & & \\
\hline C7 & 6 & 6 & 800 & 200 & & & & & & \\
\hline
\end{tabular}

\subsection{Gravity load design of flat plates}

The service dead load of the slab is assumed to be composed of the self-weight of the slab and a uniform partition weight of $1.0 \mathrm{kPa}$. The service live load is taken as $1.9 \mathrm{kPa}$ and 1.0 $\mathrm{kPa}$ for the floor and roof to represent residential buildings. The slab of each connection is designed for the gravity load composed of the dead and live loads using the direct design method of $(\mathrm{A} 23.3-04,2004)$. The layouts of the top and bottom slab reinforcements are shown in Fig. 2. The reinforcement used for each designed connection is given in Table 2. 


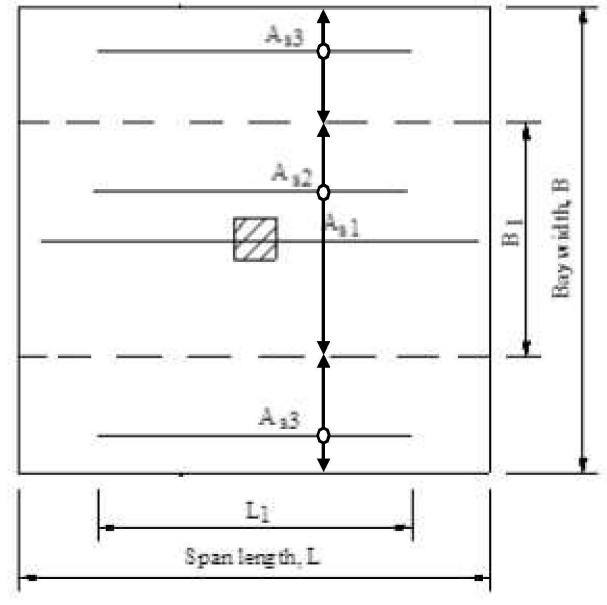

Top reinforcement

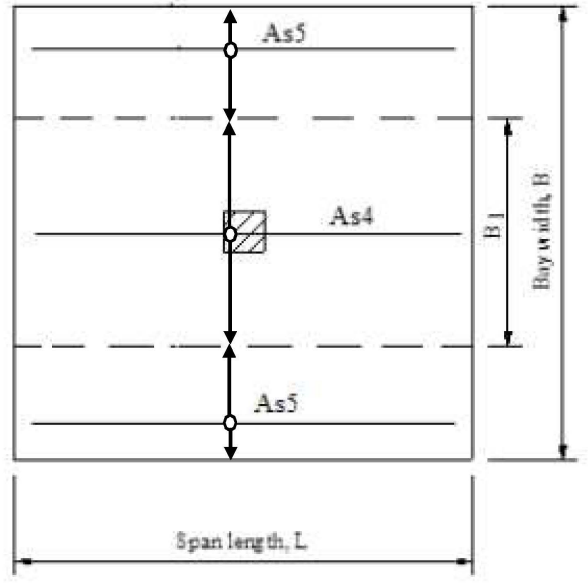

Bottom reinforcement

Fig. 2 Reinforcement layout of a typical slab.

Table 2: Top and bottom reinforcements of connections designed for gravity load only

\begin{tabular}{|c|c|c|c|c|c|c|c|c|c|}
\hline Connection & $\begin{array}{c}\mathrm{L} \\
(\mathrm{m})\end{array}$ & $\begin{array}{c}\text { B } \\
(\mathrm{m})\end{array}$ & $\begin{array}{l}\mathrm{L}_{1} \\
(\mathrm{~m})\end{array}$ & $\begin{array}{l}\mathrm{B}_{1} \\
(\mathrm{~m})\end{array}$ & $A_{s 1}$ & $A_{\mathrm{s} 2}$ & $A_{83}$ & $A_{s 4}$ & $\mathrm{~A}_{\mathrm{s} 5}$ \\
\hline $\mathrm{C} 1$ & 4 & 6 & 3 & 2 & $\begin{array}{c}\text { 3-10M@200 } \\
\mathrm{mm}\end{array}$ & $\begin{array}{c}10 \mathrm{M} @ 200 \\
\mathrm{~mm}\end{array}$ & $\begin{array}{c}10 \mathrm{M} \\
@ 250 \\
\mathrm{~mm}\end{array}$ & $\begin{array}{c}10 \mathrm{M} @ \\
250 \\
\mathrm{~mm}\end{array}$ & $\begin{array}{c}10 \mathrm{M} \\
@ 250 \\
\mathrm{~mm}\end{array}$ \\
\hline $\mathrm{C} 2$ & 6 & 6 & 4 & 3 & $\begin{array}{c}\text { 3-15M@250 } \\
\mathrm{mm}\end{array}$ & $\begin{array}{c}15 \mathrm{M} @ 250 \\
\mathrm{~mm}\end{array}$ & $\begin{array}{c}15 \mathrm{M} \\
@ 500 \\
\mathrm{~mm}\end{array}$ & $\begin{array}{c}10 \mathrm{M} @ \\
200 \\
\mathrm{~mm}\end{array}$ & $\begin{array}{c}10 \mathrm{M} \\
@ 250 \\
\mathrm{~mm}\end{array}$ \\
\hline $\mathrm{C} 3$ & 8 & 6 & 6 & 3 & $\begin{array}{c}3-15 \mathrm{M} @ 170 \\
\mathrm{~mm}\end{array}$ & $\begin{array}{c}15 \mathrm{M} @ 170 \\
\mathrm{~mm}\end{array}$ & $\begin{array}{c}15 \mathrm{M} \\
@ 370 \\
\mathrm{~mm}\end{array}$ & $\begin{array}{c}15 \mathrm{M} @ \\
300 \\
\mathrm{~mm}\end{array}$ & $\begin{array}{c}15 \mathrm{M} \\
@ 370 \\
\mathrm{~mm}\end{array}$ \\
\hline $\mathrm{C} 4$ & 6 & 4 & 4 & 2 & $\begin{array}{c}\text { 3-10M@135 } \\
\text { mm }\end{array}$ & $\begin{array}{c}10 \mathrm{M} @ 135 \\
\mathrm{~mm}\end{array}$ & $\begin{array}{c}10 \mathrm{M} \\
@ 250 \\
\mathrm{~mm}\end{array}$ & $\begin{array}{c}10 \mathrm{M} @ \\
250 \\
\mathrm{~mm}\end{array}$ & $\begin{array}{c}10 \mathrm{M} \\
@ 250 \\
\mathrm{~mm}\end{array}$ \\
\hline C5 & 6 & 8 & 4 & 3 & $\begin{array}{c}\text { 3-15M@225 } \\
\text { mm }\end{array}$ & $\begin{array}{c}15 \mathrm{M} @ 225 \\
\mathrm{~mm}\end{array}$ & $\begin{array}{c}15 \mathrm{M} \\
@ 370 \\
\mathrm{~mm}\end{array}$ & $\begin{array}{c}15 \mathrm{M} @ \\
370 \\
\mathrm{~mm}\end{array}$ & $\begin{array}{c}15 \mathrm{M} \\
@ 370 \\
\mathrm{~mm}\end{array}$ \\
\hline C6 & 6 & 6 & 4 & 3 & $\begin{array}{c}\text { 3-15M@245 } \\
\mathrm{mm}\end{array}$ & $\begin{array}{c}15 \mathrm{M} @ 245 \\
\mathrm{~mm}\end{array}$ & $\begin{array}{c}15 \mathrm{M} \\
@ 500 \\
\mathrm{~mm}\end{array}$ & $\begin{array}{c}10 \mathrm{M} @ \\
195 \\
\mathrm{~mm}\end{array}$ & $\begin{array}{c}10 \mathrm{M} \\
@ 250 \\
\mathrm{~mm}\end{array}$ \\
\hline $\mathrm{C} 7$ & 6 & 6 & 4 & 3 & $\begin{array}{c}\text { 3-15M@250 } \\
\mathrm{mm}\end{array}$ & $\begin{array}{c}15 \mathrm{M} @ 250 \\
\mathrm{~mm}\end{array}$ & $\begin{array}{c}15 \mathrm{M} \\
@ 500 \\
\mathrm{~mm}\end{array}$ & $\begin{array}{c}10 \mathrm{M} @ \\
205 \\
\mathrm{~mm}\end{array}$ & $\begin{array}{c}10 \mathrm{M} \\
@ 250 \\
\mathrm{~mm}\end{array}$ \\
\hline
\end{tabular}




\subsection{Lateral load design of flat plates}

The slab-column connection of each configuration is modelled as an elastic 2D, Fig. 1 using the sectional properties recommended in (A23.3-04, 2004). The effective moment of inertia for the slabs, $I_{e}$ was taken as 0.2 times the gross moment of inertia, $I_{g}$. For the column, $I_{e}$ was taken equal to $\alpha_{c} l_{e}$ where $\alpha_{c}$ is a factor to account for the effect of the column axial load, $P_{s}$ and is given by Eq. (1).

$$
\alpha_{c}=0.5+0.6 \frac{P_{s}}{f_{c}^{\prime} A_{g}} \leq 1.0
$$

Where, $A_{g}=$ gross area of column section

The lateral load-inter-storey drift curve of a typical concrete building designed according to current seismic standards is shown in Fig. 3. The behaviour is expected to be elastic until a yield load of $V_{y}$. This is followed by plastic deformations until reaching failure. The maximum inter-storey drift can be assumed to be $2.5 \%$ (NBCC 2010). Based on the equal displacement principle, $V_{y}$ can be calculated based on the corresponding elastic load $V_{e}$

$\left(V_{y}=\frac{V_{e} I_{E}}{R_{d} R_{0}}\right)$. The importance factor $I_{E}$, ductility factor $R_{d}$ and over-strength factor $R_{0}$ are taken as 1, 1.5 and 1.3 (NBCC 2010). Service lateral loads corresponding to a drift of $2.5 \%$ in both directions are determined and used to design the slab. The reinforcement values are given in Table 3.

\subsection{Columns}

Square columns of dimensions 600,700 , and $800 \mathrm{~mm}$ reinforced with 16-25M, 16-30M, and 16-25M bars, respectively, are assumed for all connections. 10M ties are used for all 
columns. Their spacing is $375 \mathrm{~mm}$ for the $600 \mathrm{~mm}$ and $800 \mathrm{~mm}$ columns and $475 \mathrm{~mm}$ for the $700 \mathrm{~mm}$ column. The strong column-weak slab requirement is satisfied for all connections.

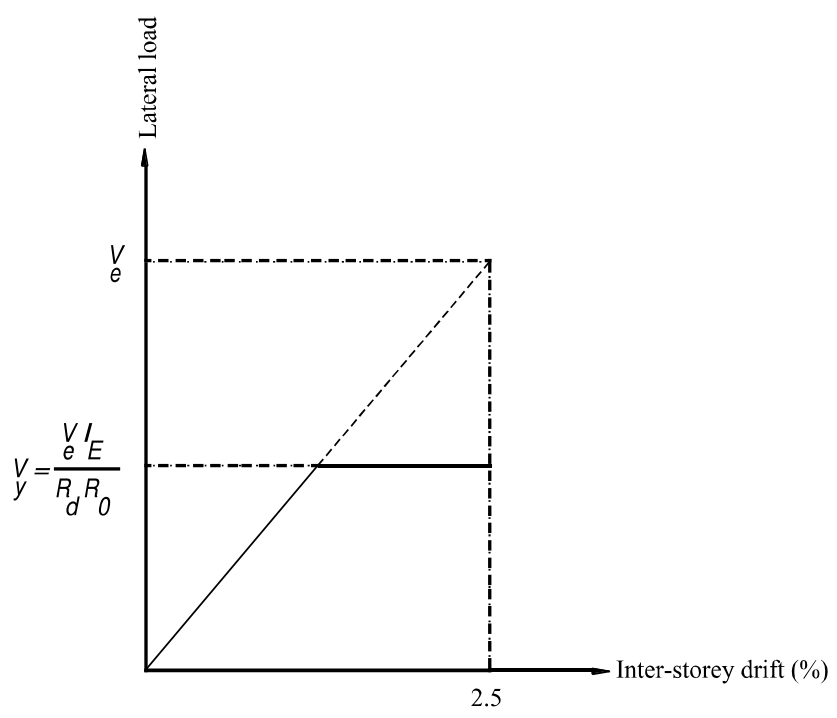

Fig. 3 Lateral load-inter-storey drift curve of a typical concrete building.

Table 3: Top and bottom reinforcements of connections designed for gravity and lateral loads

\begin{tabular}{|l|c|c|c|c|c|c|c|c|c|}
\hline Connection & $\begin{array}{c}\mathrm{L} \\
(\mathrm{m})\end{array}$ & $\begin{array}{c}\mathrm{B} \\
(\mathrm{m})\end{array}$ & $\begin{array}{c}\mathrm{L}_{1} \\
(\mathrm{~m})\end{array}$ & $\begin{array}{c}\mathrm{B}_{1} \\
(\mathrm{~m})\end{array}$ & $\mathrm{A}_{\mathrm{s} 1}$ & $\mathrm{~A}_{\mathrm{s} 2}$ & $\mathrm{~A}_{\mathrm{s} 3}$ & $\mathrm{~A}_{\mathrm{s} 4}$ & $\mathrm{~A}_{\mathrm{s} 5}$ \\
\hline $\mathrm{C} 1$ & 4 & 6 & 3 & 2 & $\begin{array}{c}5-20 \mathrm{M} @ 135 \\
\mathrm{~mm}\end{array}$ & $\begin{array}{c}20 \mathrm{M} @ 135 \\
\mathrm{~mm}\end{array}$ & $\begin{array}{c}15 \mathrm{M} @ 500 \\
\mathrm{~mm}\end{array}$ & $\begin{array}{c}15 \mathrm{M} @ 155 \\
\mathrm{~mm}\end{array}$ & $\begin{array}{c}15 \mathrm{M} @ \\
500 \mathrm{~mm}\end{array}$ \\
\hline $\mathrm{C} 2$ & 6 & 6 & 4 & 3 & $\begin{array}{c}7-20 \mathrm{M} @ 125 \\
\mathrm{~mm}\end{array}$ & $\begin{array}{c}20 \mathrm{M} @ 125 \\
\mathrm{~mm}\end{array}$ & $\begin{array}{c}15 \mathrm{M} @ 500 \\
\mathrm{~mm}\end{array}$ & $\begin{array}{c}15 \mathrm{M} @ 200 \\
\mathrm{~mm}\end{array}$ & $\begin{array}{c}10 \mathrm{M} @ \\
250 \mathrm{~mm}\end{array}$ \\
\hline $\mathrm{C} 3$ & 8 & 6 & 6 & 3 & $\begin{array}{c}9-20 \mathrm{M} @ 105 \\
\mathrm{~mm}\end{array}$ & $\begin{array}{c}20 \mathrm{M} @ 105 \\
\mathrm{~mm}\end{array}$ & $\begin{array}{c}15 \mathrm{M} @ 370 \\
\mathrm{~mm}\end{array}$ & $\begin{array}{c}15 \mathrm{M} @ 215 \\
\mathrm{~mm}\end{array}$ & $\begin{array}{c}15 \mathrm{M} @ \\
370 \mathrm{~mm}\end{array}$ \\
\hline $\mathrm{C} 4$ & 6 & 4 & 4 & 2 & $\begin{array}{c}5-20 \mathrm{M} @ 140 \\
\mathrm{~mm}\end{array}$ & $\begin{array}{c}20 \mathrm{M} @ 140 \\
\mathrm{~mm}\end{array}$ & $\begin{array}{c}15 \mathrm{M} @ 500 \\
\mathrm{~mm}\end{array}$ & $\begin{array}{c}15 \mathrm{M} @ 210 \\
\mathrm{~mm}\end{array}$ & $\begin{array}{c}15 \mathrm{M} @ \\
500 \mathrm{~mm}\end{array}$ \\
\hline $\mathrm{C} 5$ & 6 & 8 & 4 & 3 & $\begin{array}{c}9-20 \mathrm{M} @ 105 \\
\mathrm{~mm}\end{array}$ & $\begin{array}{c}20 \mathrm{M} @ 105 \\
\mathrm{~mm}\end{array}$ & $\begin{array}{c}15 \mathrm{M} @ 370 \\
\mathrm{~mm}\end{array}$ & $\begin{array}{c}15 \mathrm{M} @ 155 \\
\mathrm{~mm}\end{array}$ & $\begin{array}{c}15 \mathrm{M} @ \\
370 \mathrm{~mm}\end{array}$ \\
\hline $\mathrm{C} 6$ & 6 & 6 & 4 & 3 & $\begin{array}{c}7-20 \mathrm{M} @ 130 \\
\mathrm{~mm}\end{array}$ & $\begin{array}{c}20 \mathrm{M} @ 130 \\
\mathrm{~mm}\end{array}$ & $\begin{array}{c}15 \mathrm{M} @ 500 \\
\mathrm{~mm}\end{array}$ & $\begin{array}{c}15 \mathrm{M} @ 205 \\
\mathrm{~mm}\end{array}$ & $\begin{array}{c}10 \mathrm{M} @ \\
250 \mathrm{~mm}\end{array}$ \\
\hline $\mathrm{C} 7$ & 6 & 6 & 4 & 3 & $\begin{array}{c}7-20 \mathrm{M} @ 120 \\
\mathrm{~mm}\end{array}$ & $\begin{array}{c}20 \mathrm{M} @ 120 \\
\mathrm{~mm}\end{array}$ & $\begin{array}{c}15 \mathrm{M} @ 500 \\
\mathrm{~mm}\end{array}$ & $\begin{array}{c}15 \mathrm{M} @ 195 \\
\mathrm{~mm}\end{array}$ & $\begin{array}{c}10 \mathrm{M} @ \\
250 \mathrm{~mm}\end{array}$ \\
\hline
\end{tabular}




\section{Analytical modelling and results}

SeismoStruct computer program (SeismoSoft 2007) is used to model each connection using the grillage method. A grid spacing of $250.0 \mathrm{~mm}$ was used for both $4 \times 6 \mathrm{~m}$ and $6 \times 6 \mathrm{~m}$ slabs. For $8 \times 6 \mathrm{~m}$ slab, the grid spacing was increased to $333.3 \mathrm{~mm}$. To predict the factored capacity, resistance factors for concrete and steel were taken as 0.65 and 0.85 (A23.3-04, 2004). The concrete strength was also reduced by a factor of 0.9 to account for the differences between the in-place strength and the strength of standard cylinder (A23.3-04, 2004). Gravity loads were first applied and then static pushover analysis was performed until failure. For all of the considered cases, the developed shear forces were lower than the slab shear capacity calculated using the general method of A23.3-04 (2004). Flexural failure initiated when the concrete strain reached a concrete strain of 0.0035 (A23.3-04, 2004). This failure mechanism was expected as modern standards ensure that a brittle shear failure will not occur.

The nominal and factored moments $\left(M_{n}\right.$ and $\left.M_{r}\right)$ at which the slabs failed are summarized in Table 4. Nominal and factored effective slab widths for each configuration were calculated by equalizing the capacity of the slab section and the failure moment. The corresponding effective slab width factors $\left(\alpha_{n}\right.$ and $\left.\alpha_{r}\right)$ are calculated as the ratios of effective slab widths to the corresponding bay widths. Their values are given in Table 4 for gravity load designed frames (GL) and lateral load designed frames, moment resisting frames (MRF). For the considered cases, $\alpha_{n}$ and $\alpha_{r}$ are found to be varying from 0.087 to 0.353 and from 0.082 to 0.318 , respectively. 
Table 4: Nominal and factored ultimate moments $\left(M_{n}\right.$ and $\left.M_{r}\right)$ and effective slab width factors $\left(\alpha_{n}\right.$ and $\left.\alpha_{r}\right)$ of different connections.

\begin{tabular}{|c|c|c|c|c|c|c|c|}
\hline Connection & $\frac{P}{P_{1}}$ & $\frac{P_{f}}{P_{f 1}}$ & Flat plate system & $M_{n}(\mathrm{kN} . \mathrm{m})$ & $\alpha_{n}$ & $M_{r}(\mathrm{kN} . \mathrm{m})$ & $\alpha_{r}$ \\
\hline \multirow{3}{*}{$\mathrm{C} 1$} & 1 & 1 & $\begin{array}{c}\text { GL } \\
\text { MRF }\end{array}$ & $\begin{array}{c}82.72 \\
124.35 \\
\end{array}$ & $\begin{array}{l}0.312 \\
0.110 \\
\end{array}$ & $\begin{array}{l}62.25 \\
97.12 \\
\end{array}$ & $\begin{array}{l}0.278 \\
0.105 \\
\end{array}$ \\
\hline & 7 & 7 & $\begin{array}{c}\text { GL } \\
\text { MRF }\end{array}$ & $\begin{array}{c}71.47 \\
111.22\end{array}$ & $\begin{array}{l}0.270 \\
0.098\end{array}$ & $\begin{array}{l}53.25 \\
87.00\end{array}$ & $\begin{array}{l}0.238 \\
0.094\end{array}$ \\
\hline & 14 & 14 & $\begin{array}{c}\text { GL } \\
\text { MRF }\end{array}$ & $\begin{array}{l}60.22 \\
98.85\end{array}$ & $\begin{array}{l}0.227 \\
0.087\end{array}$ & $\begin{array}{l}43.83 \\
75.75\end{array}$ & $\begin{array}{l}0.196 \\
0.082\end{array}$ \\
\hline \multirow{3}{*}{$\mathrm{C} 2$} & 1 & 1 & $\begin{array}{c}\text { GL } \\
\text { MRF }\end{array}$ & $\begin{array}{l}11.33 \\
143.48 \\
\end{array}$ & $\begin{array}{l}0.277 \\
0.145 \\
\end{array}$ & $\begin{array}{c}87.56 \\
113.81 \\
\end{array}$ & $\begin{array}{l}0.259 \\
0.141 \\
\end{array}$ \\
\hline & 7 & 7 & $\begin{array}{c}\text { GL } \\
\text { MRF }\end{array}$ & $\begin{array}{c}96.26 \\
123.98\end{array}$ & $\begin{array}{l}0.239 \\
0.125\end{array}$ & $\begin{array}{l}75.56 \\
97.31\end{array}$ & $\begin{array}{l}0.223 \\
0.121\end{array}$ \\
\hline & 14 & 14 & $\begin{array}{c}\text { GL } \\
\text { MRF }\end{array}$ & $\begin{array}{c}81.29 \\
104.48\end{array}$ & $\begin{array}{l}0.202 \\
0.105\end{array}$ & $\begin{array}{l}63.56 \\
80.81\end{array}$ & $\begin{array}{l}0.187 \\
0.100\end{array}$ \\
\hline \multirow{3}{*}{ C3 } & 1 & 1 & $\begin{array}{c}\text { GL } \\
\text { MRF } \\
\end{array}$ & $\begin{array}{r}286.93 \\
378.81 \\
\end{array}$ & $\begin{array}{l}0.293 \\
0.188 \\
\end{array}$ & $\begin{array}{r}226.78 \\
307.41 \\
\end{array}$ & $\begin{array}{l}0.275 \\
0.184 \\
\end{array}$ \\
\hline & 7 & 7 & $\begin{array}{c}\text { GL } \\
\text { MRF }\end{array}$ & $\begin{array}{l}264.43 \\
345.06\end{array}$ & $\begin{array}{l}0.270 \\
0.171\end{array}$ & $\begin{array}{l}206.16 \\
277.41\end{array}$ & $\begin{array}{l}0.250 \\
0.166\end{array}$ \\
\hline & 14 & 14 & $\begin{array}{c}\text { GL } \\
\text { MRF }\end{array}$ & $\begin{array}{l}240.06 \\
315.06\end{array}$ & $\begin{array}{l}0.245 \\
0.156\end{array}$ & $\begin{array}{l}188.16 \\
249.28\end{array}$ & $\begin{array}{l}0.228 \\
0.149\end{array}$ \\
\hline \multirow{3}{*}{ C4 } & 1 & 1 & $\begin{array}{c}\text { GL } \\
\text { MRF }\end{array}$ & $\begin{array}{l}102.15 \\
147.15\end{array}$ & $\begin{array}{l}0.353 \\
0.186\end{array}$ & $\begin{array}{c}77.63 \\
116.63\end{array}$ & $\begin{array}{l}0.318 \\
0.179\end{array}$ \\
\hline & 7 & 7 & $\begin{array}{c}\text { GL } \\
\text { MRF }\end{array}$ & $\begin{array}{c}90.15 \\
131.40\end{array}$ & $\begin{array}{l}0.311 \\
0.165\end{array}$ & $\begin{array}{c}68.25 \\
103.88\end{array}$ & $\begin{array}{l}0.279 \\
0.159\end{array}$ \\
\hline & 14 & 14 & $\begin{array}{c}\text { GL } \\
\text { MRF }\end{array}$ & $\begin{array}{c}78.52 \\
115.65\end{array}$ & $\begin{array}{l}0.271 \\
0.146\end{array}$ & $\begin{array}{l}59.25 \\
90.38\end{array}$ & $\begin{array}{l}0.242 \\
0.139\end{array}$ \\
\hline \multirow{3}{*}{ C5 } & 1 & 1 & $\begin{array}{c}\text { GL } \\
\text { MRF }\end{array}$ & $\begin{array}{l}253.17 \\
335.67 \\
\end{array}$ & $\begin{array}{c}0.22 \\
0.130 \\
\end{array}$ & $\begin{array}{l}193.99 \\
267.12\end{array}$ & $\begin{array}{l}0.204 \\
0.125\end{array}$ \\
\hline & 7 & 7 & $\begin{array}{c}\text { GL } \\
\text { MRF }\end{array}$ & $\begin{array}{l}230.67 \\
307.54\end{array}$ & $\begin{array}{l}0.205 \\
0.119\end{array}$ & $\begin{array}{l}176.18 \\
242.74\end{array}$ & $\begin{array}{l}0.185 \\
0.114\end{array}$ \\
\hline & 14 & 14 & $\begin{array}{c}\text { GL } \\
\text { MRF }\end{array}$ & $\begin{array}{l}206.29 \\
277.54\end{array}$ & $\begin{array}{l}0.183 \\
0.107 \\
\end{array}$ & $\begin{array}{l}156.87 \\
216.49\end{array}$ & $\begin{array}{l}0.165 \\
0.101 \\
\end{array}$ \\
\hline \multirow{3}{*}{ C6 } & 1 & 1 & $\begin{array}{c}\text { GL } \\
\text { MRF }\end{array}$ & $\begin{array}{l}11.98 \\
143.48\end{array}$ & $\begin{array}{l}0.278 \\
0.145\end{array}$ & $\begin{array}{c}87.56 \\
113.81\end{array}$ & $\begin{array}{l}0.259 \\
0.141\end{array}$ \\
\hline & 7 & 7 & $\begin{array}{c}\text { GL } \\
\text { MRF }\end{array}$ & $\begin{array}{c}96.74 \\
123.98\end{array}$ & $\begin{array}{l}0.240 \\
0.125\end{array}$ & $\begin{array}{l}75.93 \\
98.06\end{array}$ & $\begin{array}{l}0.225 \\
0.122\end{array}$ \\
\hline & 14 & 14 & $\begin{array}{c}\text { GL } \\
\text { MRF }\end{array}$ & $\begin{array}{c}82.67 \\
105.23\end{array}$ & $\begin{array}{l}0.205 \\
0.106\end{array}$ & $\begin{array}{l}64.31 \\
81.56\end{array}$ & $\begin{array}{l}0.190 \\
0.101\end{array}$ \\
\hline \multirow{3}{*}{$\mathrm{C} 7$} & 1 & 1 & $\begin{array}{c}\text { GL } \\
\text { MRF }\end{array}$ & $\begin{array}{l}111.98 \\
143.48\end{array}$ & $\begin{array}{l}0.278 \\
0.145\end{array}$ & $\begin{array}{c}87.56 \\
113.81\end{array}$ & $\begin{array}{l}0.259 \\
0.141\end{array}$ \\
\hline & 7 & 7 & $\begin{array}{c}\text { GL } \\
\text { MRF }\end{array}$ & $\begin{array}{c}95.48 \\
123.23 \\
\end{array}$ & $\begin{array}{l}0.237 \\
0.125 \\
\end{array}$ & \begin{tabular}{|l}
75.18 \\
96.56 \\
\end{tabular} & $\begin{array}{l}0.222 \\
0.120 \\
\end{array}$ \\
\hline & 14 & 14 & $\begin{array}{c}\text { GL } \\
\text { MRF }\end{array}$ & $\begin{array}{c}80.97 \\
102.98\end{array}$ & $\begin{array}{l}0.201 \\
0.104\end{array}$ & $\begin{array}{l}62.52 \\
79.31\end{array}$ & $\begin{array}{l}0.185 \\
0.098\end{array}$ \\
\hline
\end{tabular}




\section{Discussion of analytical results}

Variations of nominal and factored effective slab width factors with span length, bay width, and column dimension at different nominal and factored axial load ratios for GL or MRF flat plates are shown in Figs. 4-6. These curves show that the nominal and factored effective slab width factors decrease as the axial load of column increases. Increasing the column axial load increases column stiffness, which reduces column rotation and limits the width of the slab contributing its capacity. $\alpha_{n}$ and $\alpha_{r}$ for MRF flat plates are less than those for GL flat plates. This is likely due to the higher reinforcement ratio for MRF as compared to GL flat plates, which decreases the slab width required to achieve the flexural capacity.

Fig. 7 shows that $\alpha_{n}$ vary from 0.202 to 0.312 for GL flat plates and from 0.087 to 0.188 for MRF flat plates as the span length changes from $4 \mathrm{~m}$ to $8 \mathrm{~m}$. It also shows that the corresponding values of $\alpha_{r}$ vary from 0.187 to 0.278 for GL flat plates and 0.082 to 0.184 for MRF flat plates. $\alpha_{n}$ and $\alpha_{r}$ did not change significantly for GL flat plates. This is likely due to the reinforcement ratio, which is governed by gravity loads. On the other hand, $\alpha_{n}$ and $\alpha_{r}$ values for MRF flat plates increase with increase in span. This is likely due to the 3D behaviour of flat plate which allows a bigger width to contribute for bigger spans if adequate reinforcement is provided.

Fig. 5 shows that $\alpha_{n}$ vary from 0.353 to 0.183 for GL flat plates and 0.186 to 0.105 for MRF flat plates as the bay width changes from $4 \mathrm{~m}$ to $8 \mathrm{~m}$. It also shows that the corresponding values of $\alpha_{r}$ vary from 0.318 to 0.165 for GL flat plates and 0.179 to 0.100 for MRF flat plates. $\alpha_{n}$ and $\alpha_{r}$ for GL and MRF flat plates decrease with the increase in bay width. Increasing bay width increases gravity moments which eventually increases design reinforcements and decreases $\alpha_{n}$ and $\alpha_{r}$. 
Fig. 6 shows that $\alpha_{n}$ vary from 0.278 to 0.201 for GL flat plates and 0.145 to 0.104 for MRF flat plates as the column dimension changes from $600 \mathrm{~mm}$ to $800 \mathrm{~mm}$. It also shows that the corresponding values of $\alpha_{r}$ vary from 0.259 to 0.185 for GL flat plates and from 0.141 to 0.098 for MRF flat plates. Column dimensions were found to have minor effect on $\alpha_{n}$ and $\alpha_{r}$. This is likely due to the small variation of column dimensions with respect to slab dimensions.

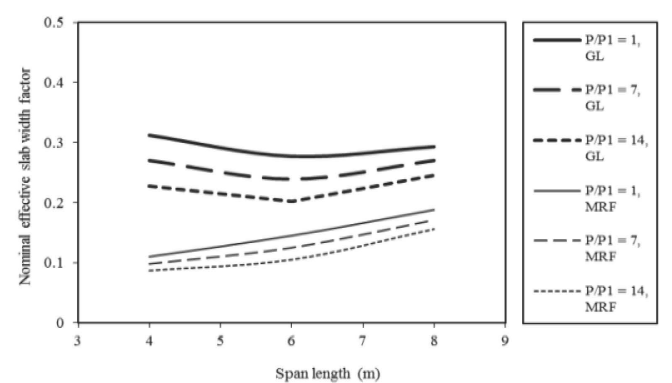

a) Nominal capacity

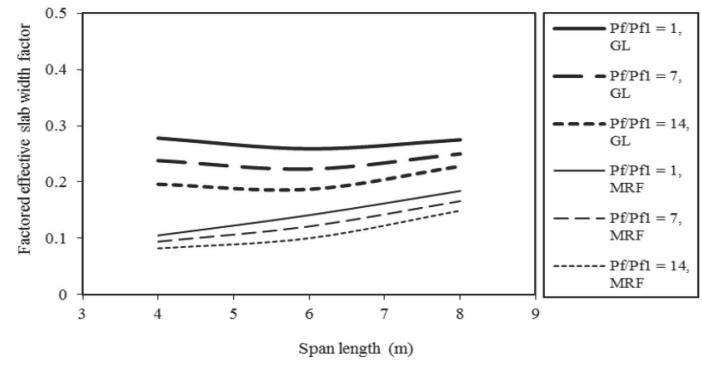

b) Factored capacity

Fig. 4 Variation of effective slab width factor with span length.

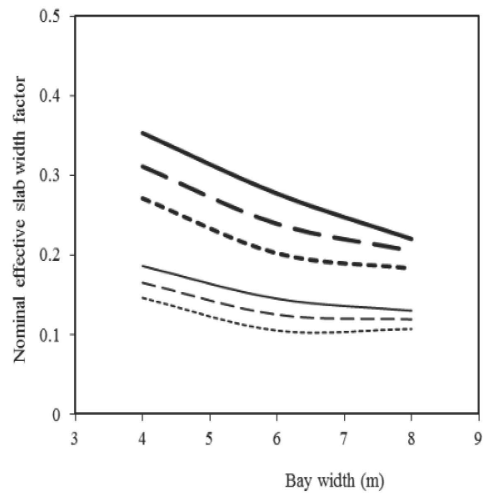

a) Nominal capacity

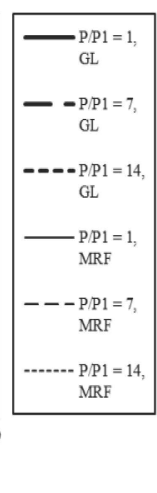

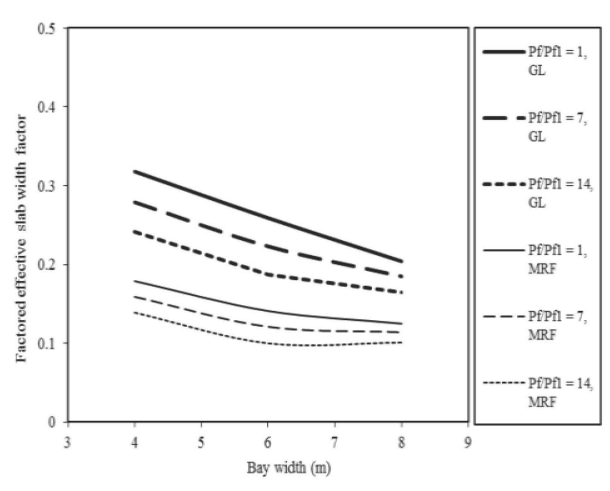

b) Factored capacity

Fig. 5 Variation of effective slab width factor with bay width. 

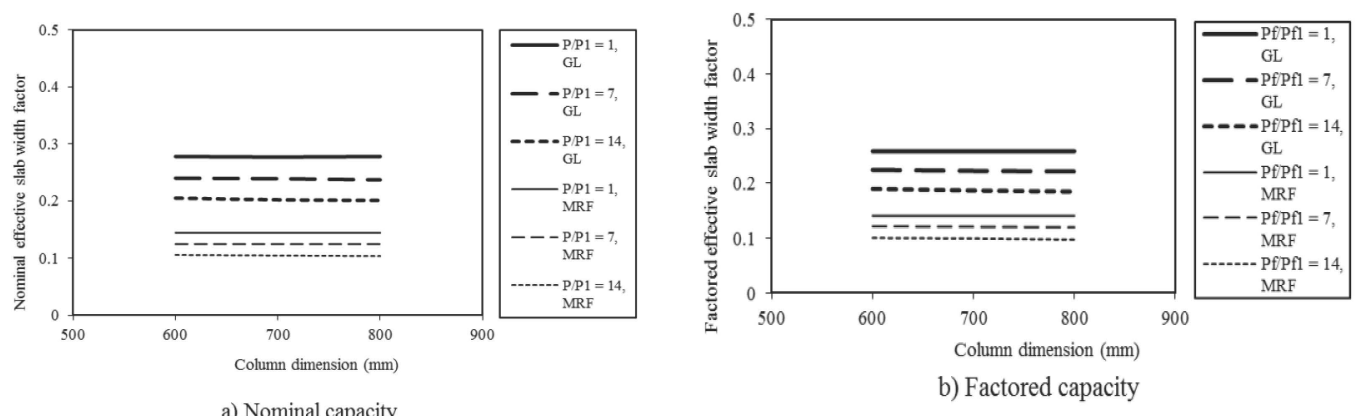

Fig. 6 Variation of effective slab width factor with column dimensions.

\section{Effective Slab Width}

Using the calculated effective slab width factors, two expressions are developed to estimate the effective width factor for GL and MRF. The effective width factor is found to be proportional to a linear function of the axial load of column $\left(\frac{P}{P_{1}}\right)$, a parabolic function of the span length $(L)$, and a parabolic function of the bay width $(B)$. This led to the following expression.

$$
\alpha=\left(A_{1} \frac{P}{P_{1}}+A_{2}\right)\left(A_{3} L^{2}+A_{4} L+A_{5}\right)\left(A_{6} B^{2}+A_{7} B+A_{8}\right)
$$

The values of $A_{1}$ through $A_{8}$ were determined using regression analysis such that the difference between the analytical values for $\alpha$ and the values determined from Eq. (4) is minimized. The expressions to estimate $\alpha_{n}$ for GL and MRF flat plates are given by Eqs. (3) and (4), respectively. $\alpha_{r}$ can be estimated by multiplying $\alpha_{n}$ by 0.919 and 0.969 for GL and MRF flat plates, respectively. 


$$
\begin{aligned}
& \alpha_{n}=10^{-12}\left(-180 \frac{P}{P_{1}}+10150\right)\left(50 L^{2}-690 L+4660\right)\left(80 B^{2}-2430 B+22720\right) \\
& \alpha_{n}=10^{-12}\left(-170 \frac{P}{P_{1}}+10130\right)\left(10 L^{2}+70 L+650\right)\left(210 B^{2}-3570 B+23360\right)
\end{aligned}
$$

Where $L=$ span length (m) and $B=$ bay width (m)

The predictions of Eqs. (3) and (4) are compared with the analytical results in Tables 5 and 6, respectively. The comparisons are also shown in Fig. 7. The predictions have minor deviation from the analytical results (deviation of \pm 0.022 ).

Table 5: Comparison of the predicted values of Eq. (3) and the analytical results

\begin{tabular}{|l|c|c|c|c|c|c|c|c|}
\hline \multirow{3}{*}{ Connection } & $\frac{P}{P_{1}}$ & $\frac{P_{f}}{P_{f 1}}$ & $\alpha_{n}$ & Eq. & Deviation & $\alpha_{r}$ & Eq. 3 & Deviation \\
& 1 & 1 & 0.312 & 0.311 & 0.001 & 0.278 & 0.286 & -0.008 \\
& 7 & 7 & 0.270 & 0.274 & -0.004 & 0.238 & 0.252 & -0.014 \\
C1 & 14 & 14 & 0.227 & 0.237 & -0.010 & 0.196 & 0.218 & -0.022 \\
\hline \multirow{3}{*}{ C2 } & 1 & 1 & 0.277 & 0.277 & 0.000 & 0.259 & 0.255 & 0.004 \\
& 7 & 7 & 0.239 & 0.244 & -0.005 & 0.223 & 0.224 & -0.001 \\
& 14 & 14 & 0.202 & 0.211 & -0.009 & 0.187 & 0.194 & -0.007 \\
\hline \multirow{3}{*}{ C3 } & 1 & 1 & 0.293 & 0.293 & 0.000 & 0.275 & 0.269 & 0.006 \\
& 7 & 7 & 0.270 & 0.257 & 0.013 & 0.250 & 0.236 & 0.014 \\
& 14 & 14 & 0.245 & 0.223 & 0.022 & 0.228 & 0.205 & 0.023 \\
\hline \multirow{3}{*}{ C4 } & 1 & 1 & 0.353 & 0.353 & 0.000 & 0.318 & 0.324 & -0.006 \\
& 7 & 7 & 0.311 & 0.310 & 0.001 & 0.279 & 0.285 & -0.006 \\
& 14 & 14 & 0.271 & 0.268 & 0.003 & 0.242 & 0.246 & -0.004 \\
\hline \multirow{3}{*}{ C5 } & 1 & 1 & 0.220 & 0.220 & 0.000 & 0.204 & 0.202 & 0.002 \\
& 7 & 7 & 0.205 & 0.193 & 0.012 & 0.185 & 0.178 & 0.007 \\
& 14 & 14 & 0.183 & 0.167 & 0.016 & 0.165 & 0.153 & 0.012 \\
\hline \multirow{2}{*}{ C7 } & 1 & 1 & 0.278 & 0.278 & 0.000 & 0.259 & 0.255 & 0.004 \\
& 7 & 7 & 0.240 & 0.244 & -0.004 & 0.225 & 0.224 & 0.001 \\
& 14 & 14 & 0.205 & 0.211 & -0.006 & 0.190 & 0.194 & -0.004 \\
\hline \multirow{2}{*}{} & 1 & 1 & 0.278 & 0.278 & 0.000 & 0.259 & 0.255 & 0.004 \\
& 7 & 7 & 0.237 & 0.244 & -0.007 & 0.222 & 0.224 & -0.002 \\
& 14 & 14 & 0.201 & 0.211 & -0.010 & 0.185 & 0.194 & -0.009 \\
\hline
\end{tabular}


Table 6: Comparison of the predicted values of Eq. (4) and the analytical results

\begin{tabular}{|l|c|c|c|c|c|c|c|c|}
\hline \multirow{3}{*}{ Connection } & $\frac{P}{P_{1}}$ & $\frac{P_{f}}{P_{f 1}}$ & $\alpha_{n}$ & Eq. & Deviation & $\alpha_{r}$ & Eq. 4 & Deviation \\
& 1 & 1 & 0.110 & 0.110 & 0.000 & 0.105 & 0.106 & -0.001 \\
C1 & 7 & 7 & 0.098 & 0.097 & 0.001 & 0.094 & 0.094 & 0.000 \\
& 14 & 14 & 0.087 & 0.085 & 0.002 & 0.082 & 0.082 & 0.000 \\
\hline \multirow{3}{*}{ C2 } & 1 & 1 & 0.145 & 0.145 & 0.000 & 0.141 & 0.140 & 0.001 \\
& 7 & 7 & 0.125 & 0.128 & -0.003 & 0.121 & 0.124 & -0.003 \\
\hline \multirow{3}{*}{ C3 } & 14 & 14 & 0.105 & 0.112 & -0.007 & 0.100 & 0.108 & -0.008 \\
\hline \multirow{3}{*}{ C4 } & 1 & 1 & 0.188 & 0.188 & 0.000 & 0.184 & 0.182 & 0.002 \\
& 7 & 7 & 0.171 & 0.166 & 0.005 & 0.166 & 0.161 & 0.005 \\
& 14 & 14 & 0.156 & 0.145 & 0.011 & 0.149 & 0.141 & 0.008 \\
\hline \multirow{3}{*}{ C5 } & 1 & 1 & 0.186 & 0.186 & 0.000 & 0.179 & 0.180 & -0.001 \\
& 7 & 7 & 0.165 & 0.164 & 0.001 & 0.159 & 0.159 & 0.000 \\
& 14 & 14 & 0.146 & 0.144 & 0.002 & 0.139 & 0.139 & 0.000 \\
\hline \multirow{2}{*}{ C6 } & 1 & 1 & 0.130 & 0.130 & 0.000 & 0.125 & 0.125 & 0.000 \\
& 7 & 7 & 0.119 & 0.115 & 0.004 & 0.114 & 0.111 & 0.003 \\
\hline \multirow{2}{*}{ C7 } & 14 & 14 & 0.107 & 0.100 & 0.007 & 0.101 & 0.097 & 0.004 \\
& 1 & 1 & 0.145 & 0.145 & 0.000 & 0.141 & 0.140 & 0.001 \\
& 7 & 7 & 0.125 & 0.128 & -0.003 & 0.122 & 0.124 & -0.002 \\
& 14 & 14 & 0.106 & 0.112 & -0.006 & 0.101 & 0.108 & -0.007 \\
\hline
\end{tabular}

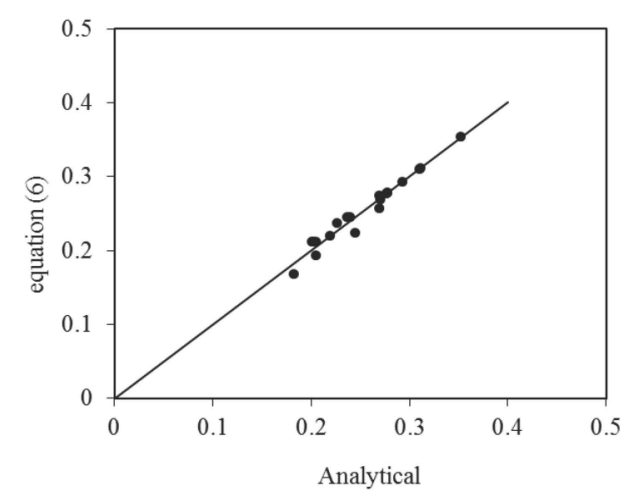

a. Eq. (3)

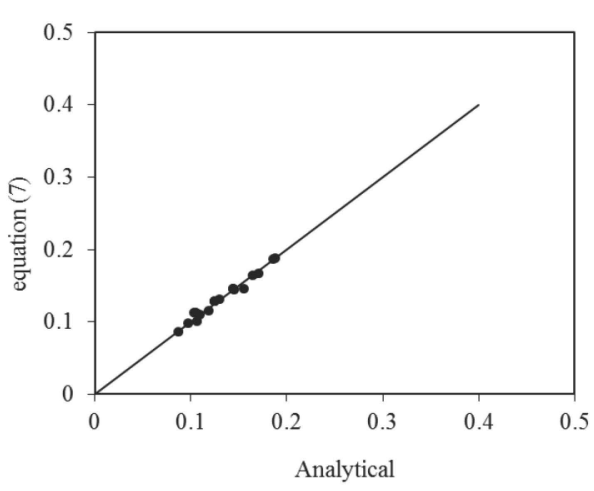

b.Eq. (4)

Fig. 7 Comparison of the predictions of the proposed equations and the analytical results. 
To further validate the proposed equations, the predictions of Eq. (3) are used to calculate the nominal capacity $\left(M_{u, E q}\right)$ of ten connections that were experimentally tested by other researchers. Comparison between the values of $M_{u}$, Eq. and the experimentally observed ultimate moments are shown in Table 7 . A maximum deviation of $10 \%$ was observed.

Table 7: Comparison of the predicted values of Eq. (3) and experimental results by others

\begin{tabular}{|c|c|c|c|c|c|c|c|c|}
\hline Experiments & Specimens & $\begin{array}{c}\text { Span } \\
\text { length } \\
(\mathrm{m})\end{array}$ & $\begin{array}{c}\text { Bay } \\
\text { width } \\
\text { (m) }\end{array}$ & $\frac{P}{P_{1}}$ & $\begin{array}{l}\text { Eq. } \\
(3)\end{array}$ & $\begin{array}{l}M_{u, E q} \\
(\mathrm{kN} . \mathrm{m})\end{array}$ & $\begin{array}{c}M_{u, e} \\
(\mathrm{kN} . \mathrm{m})\end{array}$ & $\begin{array}{c}\text { Deviation } \\
(\%)\end{array}$ \\
\hline $\begin{array}{l}\text { Pan and } \\
\text { Moehle (1988) }\end{array}$ & 3 & 3.65 & 3.65 & \multirow{4}{*}{1} & 0.417 & 49 & 52.77 & 7 \\
\hline $\begin{array}{l}\text { Robertson and } \\
\text { Durrani (1990) }\end{array}$ & $\begin{array}{c}8 \mathrm{I} \\
1 \\
2 \mathrm{C} \\
5 \mathrm{SO} \\
\end{array}$ & 2.89 & 1.98 & & 0.560 & $\begin{array}{l}32.21 \\
32.35 \\
32.35 \\
32.35 \\
\end{array}$ & $\begin{array}{l}33.33 \\
32.37 \\
33.10 \\
33.39 \\
\end{array}$ & $\begin{array}{l}3 \\
0 \\
2 \\
3 \\
\end{array}$ \\
\hline $\begin{array}{l}\text { (Farhey et al. } \\
1993)\end{array}$ & 1 & 2.68 & 2.68 & & 0.530 & 16.89 & 16.50 & -2 \\
\hline $\begin{array}{l}\text { Morrison and } \\
\text { Sozen (1981) }\end{array}$ & $\begin{array}{l}\text { S2 } \\
\text { S3 } \\
\text { S4 } \\
\text { S5 }\end{array}$ & 1.82 & 1.82 & & 0.660 & $\begin{array}{l}17.43 \\
21.66 \\
16.38 \\
17.41\end{array}$ & $\begin{array}{l}19.37 \\
20.56 \\
17.74 \\
18.75\end{array}$ & $\begin{array}{c}10 \\
-5 \\
8 \\
7\end{array}$ \\
\hline
\end{tabular}

\section{Conclusions}

In this paper, the use of grillage analysis to predict the nonlinear seismic behaviour of flat plates allowed conducting an extensive parametric study to evaluate the effective slab width required to calculate the nominal and factored resisting moment for different spans, bay widths, column dimensions, and column axial loads. Two sets of flat plate frames are designed. They represent flat plate structures designed for gravity loads and for gravity and horizontal loads. Each structure is modelled using grillage analysis and is subjected to an increasing lateral load. The resisting moment is defined using suitable failure criteria and then used to calculate the effective slab width. The nominal and factored effective slab width 
factors are found to increase with the increase of flat plate span and decrease with the increase of bay width. Column dimensions are found to have minor effects on their values. They are also found to decrease as the axial loads of column increase. GL flat plates had higher values as compared to MRF flat plates. Expressions for nominal and factored effective slab width factors are proposed. Their predictions are validated using available experimental results and found to be adequate. Nominal and factored effective slab width factors calculated in this study are applicable for buildings designed to modern design standards and for the range of parameters considered. Care should be taken when using them for other cases.

\section{References}

CSA A23.3-04 (2004), Design of Concrete Structures, Canadian Standards Association, Mississauga, Ontario, Canada.

Farhey D.N., Adin M.A., Yankelevsky D Z (1993), "RC flat slab-column subassemblages under lateral loading", ASCE Journal of Structural Engineering, 119(6), 1903-1916.

Grossman J.S. (1997), "Verification of proposed design methodologies for effective width of slabs in slab-column frames", ACI Structural Journal, 94(2), 181-196.

Hwang S.J. and Moehle J.P. (1993), “An experimental study of flat-plate structures under vertical and lateral loads", Earthquake Engineering Research Center, Report No. UCB/EERC-93/03, University of California at Berkeley, Berkeley, California, USA.

Luo Y.H. and Durrani A.J. (1995), "Equivalent beam model for flat-slab buildings-part I: interior connections", ACI Structural Journal, 92(1), 115-124. 
Mander J.B., Priestley M.J.N., Park R. (1988), “Theoretical stress-strain model for confined concrete”, ASCE Journal of Structural Engineering, 114(8), 1804-1826.

Martinez-Rueda J.E. and Elnashai A.S. (1997), "Confined concrete model under cyclic load", Materials and Structures, 30(197), 139-147.

Morrison D.G. and Sozen M.A. (1981), "Response of reinforced concrete plate-column connections to dynamic and static horizontal loads", Civil Engineering Studies, Structural Research Series, Report No. 490, University of Illinois, Urbana-Champaign, Illinois, USA.

NBCC (2010), "National Building Code of Canada", Institute for Research in Construction, National Research Council of Canada, Ottawa, Ontario, Canada.

O’Brien E.J. and Keogh D.L. (1999), "Bridge Deck Analysis”, E \& FN Spon, London, UK. Pan A.D. and Moehle J.P. (1988), "Reinforced concrete flat plates under lateral loading: an experimental study including biaxial effects", Earthquake Engineering Research Center, Report No. UCB/EERC-88/16, University of California at Berkeley, Berkeley, California, USA, $262 \mathrm{pp}$.

Park R. and Paulay T. (1972), Reinforced Concrete Structures, JOHN WILEY \& SONS, INC., Canada.

Pecknold D.A. (1975), "Slab effective width for equivalent frame analysis" ACI Structural Journal, 72(4), 135-137.

Robertson I.N. and Durrani A.J. (1990), "Seismic response of connections in indeterminate flat-slab subassemblies”, Ph.D. Dissertation, Rice University, Houston, Texas, USA. 
SeismoSoft (2007) "Seismostruct: A computer program for static and dynamic nonlinear analysis of framed structures", Available from URL: http://www.seismosoft.com.

Youssef M.A., Meshaly M.E., Chowdhury A.O. (2014) Lateral stiffness of reinforced concrete interior flat plate connections, Engineering Structures, 62-63, 23-32. 